\title{
SZOFTVERRÁDIÓN ALAPULÓ ADAPTÍV ENTRÓPIAFORRÁS GENETIKUS ALGORITMUS SEGÍTSÉGÉVEL
}

\section{ADAPTIVE, SOFTWARE RADIO BASED ENTROPY SOURCE WITH GENETIC ALGORITHM}

Répás Sándor

Óbudai Egyetem Biztonságtudományi Doktori Iskola, Cím: 1034, Magyarország, Budapest, Bécsi út 96/b.; rsandor@ahol.co.hu

\begin{abstract}
We shortly present the main application areas of random numbers, and the creation methods of them. We briefly describe the operation of the software defined radios. We present a solution to getting the help of genetic algorithm (GA) to find the optimal setup parameters. Presented methods are useful in developing adaptive systems which use time-varying entropy source.
\end{abstract}

Keywords: adaptive system, genetic algorithm, RTL-SDR, TRNG

\section{Összefoglalás}

Röviden bemutatjuk a véletlen számok főbb felhasználási területeit, és elöállítási lehetőségeiket. Nagyon röviden a szoftverrádiók müködését ismertetjük. Bemutatjuk azt, hogyan lehet genetikus algoritmus (GA) segítségével megtalálni az optimális beállítási paramétereket. A bemutatott módszerek jól használhatóak olyan adaptív rendszerek kialakítására, melyek időben változó tulajdonságú entrópia forrást alkalmaznak.

Kulcsszavak: adaptív rendszer, genetikus algoritmus, RTL-SDR, szoftverrádió, véletlenszám.

\section{Bevezetés}

A véletlen számok a kriptográfiában és a szimulációkban kiemelt jelentőséggel bírnak, ugyanakkor előállításuk nem triviális feladat. A megfelelö minőségü valódi véletlen szám (True Random Number, TRN) elöállításához elengedhetetlen fontosságú egy entrópia forrás, mely a véletlen szám generátor (Random Number Generator, RNG) bemeneteként használható, és segítségével, különböző algoritmusokat alkalmazva véletlen szám állítható elö. A rendkívül olcsó szoftverrádiók (Software Defined Radio, SDR) megjelenése, az SDR mind szélesebb körü alkalmazását idézte elö, valamint megjelent az igény az SDR-ek entrópia forrásként történő alkalmazására is [1]. Ugyanakkor nem megoldott az SDR-ek müködési paramétereinek beállítása, valamint változó körülmények esetén, a paraméterek módosítása.

A genetikus algoritmusoknak [2] az informatikai biztonság területen történő alkalmazása széles körben elterjedt. Számtalan publikáció foglalkozik a GA behatolás detektáló [3], valamint levélszemét szürő [4] alkalmazásokban történő alkalmazásával. 
A következőkben egy szoftverrádió segítségével kialakított, genetikus algoritmus segítségével megvalósított adaptív entrópiaforrást mutatunk be.

\section{Véletlen számok}

A véletlen számok megjósolhatatlanok. A véletlen számokból álló sorozat tagjai közt nem található összefüggés, vagy mintázat.

\subsection{Előállításuk}

A véletlen számok előállítása történhet:

- valós véletlen szám generátorral (True Random Number Generator, TRNG); A hagyományos számítógépek, nem képesek valós véletlen számokat előállítani, általában valamilyen külső eseményt használhatnak fel erre a célra (pl. megszakítás, egérmozgás);

- álvéletlen szám generátorral (Pseudo Random Number Generator, PRNG); valamilyen matematikai algoritmus segítségével állítják elö a véletlennek tünő számsorozatot, melyhez kezdeti bemenő paramétert alkalmaznak.

\subsection{Felhasználásuk}

A véletlen számok sok területen nélkülözhetetlenek, melyekből csak kettőt emelünk ki:

- szimuláció: általában PRNG segítségével elöállított számokra van szükség, sokszor oly módon, hogy többszöri futtatás is ugyanazt az álvéletlen sorozatot eredményezze (ez azonos PRNG és kezdeti bemenő paraméterértékkel érhetö el);

- titkosítás: a megfelelő biztonság eléréséhez valós véletlen számokra van szükség, vagy olyan álvéletlen számokra, melyek a támadók számára nem reprodukálhatóak (nem ismert PRNG algoritmus, és/vagy kezdeti bemenő érték).

\section{Szoftverrádió}

A szoftverrádió alapelve, hogy az analóg-digitális átalakítás az antennához a lehető legközelebb történjen meg, és a jelfeldolgozás minél nagyobb része történhessen meg digitális módszerekkel. Ezáltal az SDR müködése újradefiniálható, nincs szükség különféle eszközökre, hanem egységes hardveren, eltérő szoftverek segítségével kivitelezhetőek a kívánt funkciók [4-5].

Az RTL2832U félvezetöre épülő eszközök [7], valamint az RTL-SDR programkönyvtár [8] megjelenésével, bárki számára elérhetővé váltak az SDR eszközök. Egy RTL2832U-ra épülő USB DVB-T vevő már 10 USD alatt is elérhető, és kiválóan használható SDR-ként, így számos érdekes kutatás készült segítségével, valamint egyre szélesebb körben alkalmazzák az oktatás területén is [9]. Egy ilyen eszköz, az alkalmazott tuner típusától függően, akár 52 és 2200Mhz közötti tartományban, 7bites felbontással 2,56MS/s mintavételezéssel is képes lehet az érzékelt jelet IQ értékekként a számítógépnek továbbítani [7-8].

\section{Véletlen számok előállítása SDR és GA segítségével}

\subsection{SDR mint entrópia forrás}

A különböző elektromágneses zajok entrópia forrásként történő felhasználása általánosan elterjedt. Erre a célra az SDR is jól használható. Elégséges egy nem, vagy alig használt frekvenciára hangolni, majd az IQ demodulátor kimeneteit felhasználni. A legjobb eredmény akkor érhető el, ha a 7 bites kimenetből csak a legalacsonyabb helyi értéket használjuk fel.

Problémaként merül fel azonban, annak a frekvenciának a beállítása, mely a leginkább megfelel a véletlen számok generálásához, ráadásul ez a frekvencia helytől és időtől is függ, tehát adaptív rendszer kialakításra van szükség. A probléma megoldá- 
sára kiválóan alkalmazható a genetikus algoritmus.

A rendszer blokkvázlata az 1. ábrán látható.

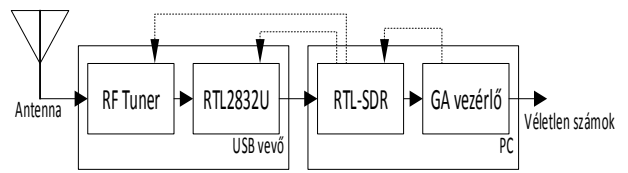

1. ábra. A GA segitségével vezérelt $S D R$ entrópia forrás blokkvázlata

A tuner és az SDR mintavételezési beállításait a GA segítségével (az RTL-SDR interfészen keresztül) beállítjuk, majd következik a mintavételezés, a feldolgozás, végül a kimeneten megjelenik az érzékelt bitsorozat.

\subsection{A GA vezérlő}

A vezérlés sokféle módszerrel megoldható, a következőkben csak egy lehetséges megoldást ismertetünk.

\subsubsection{Egyedek és populáció}

Húsz egyedből álló populáció került kialakításra. Az alacsony szám oka, hogy a mintavételezés egy eszköz alkalmazásával csak egymás után végezhető el, így viszonylag hosszú időt vesz igénybe. Az egyes egyedek két tulajdonsággal rendelkeznek: Mintavételi sebesség, frekvencia. A tulajdonságok jellemzőit az 1. táblázat tartalmazza.

Az egyes tulajdonságok a táblázatban megadott bitszámon egész értékként kerülnek ábrázolásra. A választott értékek a mutáció ismertetésénél kerülnek indoklásra.

A vezérlés müködése a $\mathbf{2}$. ábrán látható.

1. táblázat. Egyed tulajdonságai

\begin{tabular}{|c|c|c|}
\hline Tulajdonság & $\begin{array}{c}\text { mintavétel } \\
(\mathrm{S} / \mathrm{s})\end{array}$ & $\begin{array}{c}\text { frekvencia } \\
(\mathrm{Hz})\end{array}$ \\
\hline minimum & 1751425 & 692258177 \\
\hline maximum & $2800 \mathrm{k}$ & $1766 \mathrm{M}$ \\
\hline hossz (bit) & 20 & 30 \\
\hline
\end{tabular}

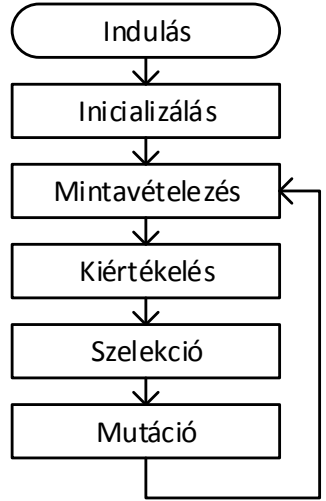

2. ábra. $A$ GA vezérlés müködése

\subsubsection{Inicializálás}

A kezdeti populáció elöállítása során az egyes egyedek mindkét tulajdonságát véletlenszerüen értékekre állítjuk be. Azonos egyedek nem kerülhetnek a populációba.

\subsubsection{Mintavételezés}

A mintavételezés során, minden egyed tulajdonságai által meghatározott paraméterekkel meghívásra kerül az RTL-SDR, mely minden esetben 8MB-os állományokat hoz létre. (A felhasználást megelözően, az egyed tulajdonságaiként megadott mintavételi és frekvenciaértékek növelésre kerülnek a minimum értékekkel.)

Az előzetes feldolgozás során az állományokból a legalacsonyabb helyi értékü bitek átmásolásra kerülnek új állományokba, melyek mérete így 1MB-ra csökken.

\subsubsection{Kiértékelés}

A kiértékelés során minden egyedre meghatározásra kerül a fitneszfüggvény értéke.

A fitneszfüggvény kialakításánál fontos szempont a végrehajtási sebesség, így az egyes egyedekhez tartozó állományoknak csak a következő három tulajdonsága kerül vizsgálatra, majd a kapott eredmények kerülnek összegzésre: 
- $X^{2}$ eloszlással számított értéket meghaladó esetek számának 50\%-tól eltérése;

- Monte-Carlo szimuláció segítségével meghatározott $\pi$ értékének, a tényleges értéktől való eltérése;

- Soros korrelációs együttható 0 -ától való eltérése.

Az értékek kiszámítása az ent [10] külső program meghívásával végezhető el egyszerüen.

\subsubsection{Szelekció}

A fitneszfüggvény értékek alapján csökkenő sorba rendezett egyedek közül, az első tíz kiválasztásra kerül, melyek változatlanul bekerülnek az új populációba. A kiválasztott egyedekből, azon egyedekhez tartozó minták, melyek elérik a fitnesz függvény minimálisan megadott értékét, kerülnek továbbításra a véletlen szám generátor bemenetére. (Ez biztosítja azt, hogy csak megfelelően véletlen eloszlású bitsorozat kerülhessen ki a rendszerböl.)

\subsubsection{Mutáció}

Ez az első tíz egyed képezi az alapját a mutációnak is. Minden egyed egy új egyednek képezi az alapját. Az új egyed képzésekor, annak mindkét tulajdonságánál véletlenszerủen kiválasztásra kerül egy-egy bit, melynek értéke negálásra kerül.

Ha a populáció két ugyanolyan egyedet tartalmazna, úgy másik bit kerül negálásra.

\section{Következtetések}

Genetikus algoritmus segítségével elóállítató egy adaptív entrópia forrás, mely a jelenleg is elérhető RTL-entropy alkalmazásánál lényegesen nehezebben támadható. Ezáltal titkosítási feladatokra alkalmazása sokkal jobban megfelel. [11]

A jövőben külső programok meghívása helyett, integrált megoldás elkészítését tervezzük, mely ugyan tanulásra nehezebben alkalmazható, de valós felhasználásra jobban megfelel. Több rádió egyidejü alkalmazásának és a párhuzamos kódfuttatásnak megoldása is fontos feladat.

\section{Szakirodalmi hivatkozások}

[1] Warren, Paul: RTL-Entropy, https://rtlentropy.org/, Elérve: 2015. október 29.

[2] Coley, David A: An introduction to genetic algorithms for scientists and engineers. World scientific, 1999.

[3] Chittur, Adhitya: Model generation for an intrusion detection system using genetic algorithms, http://www1. cs. columbia. edu/ids/publications/gaids-thesis01. pdf, Elérve: 2015. október 29.

[4] Oda, Terri, White, Tony: Immunity from spam: an analysis of an artificial immune system for junk email detection, Artificial Immune Systems, 2005. 276-289.

[5] Eged Bertalan: Elektronikai hadviselési és felderitö rendszerek integrációja korszerü digitális- és szoftver rádió technológiával, Hadmérnök, 2009. június, 274.

[6] Erdei Márk, Wagner Margit Katalin: Szoftverrádió-rendszerek: új trendek, Híradástechnika, 2005/8.

[7] RTL2832U, http://www.realtek.com.tw/products/products View .aspx ?Langid $=1 \& \mathrm{PFid}=35 \&$ Level $=4 \& \mathrm{C}$ onn $=3 \&$ ProdID=257, Elérve: 2015. október 30.

[8] OsmocomSDR -rtl-sdr, http://sdr.osmocom.org/trac/wiki/rtl-sdr, Elérve: 2015. október 30.

[9] Uengtrakul, Boonyarit, Bunnjaweht, Dahmmaet: A Cost Efficient Software Defined Radio Receiver for Demonstrating Concepts in Communication and Signal Processing using Python and RTL-SDR, Bangkok, 2014. május 6-8. 394-399.

[10] Walker, John: ENT A pseudorandom number sequence test program, http://www.fourmilab.ch/random/, Elérve: 2015. december 10.

[11] Un portrait militaire au reflet de l'insurrection hongroise, ORIENTS (ISSN: 1769-6321) 2013: (10) pp. 93-96. (2013) 